\title{
Efektivitas Penetapan PSBB Dalam Menurunkan Perilaku Konsumtif Masyarakat Pada Masa Covid-19
}

\author{
Muhammad Fikri Haekal ${ }^{1,}$, Muhammad Supian ${ }^{1}$, Winda Sabrina ${ }^{1}$ \\ ${ }^{1}$ Interdisciplinary Islamic Studies; Universitas Islam Negeri Sunan Kalijaga; JI. Laksda \\ Adisucipto, Papringan, Caturtunggal, Kec. Depok, Kabupaten Sleman, Daerah Istimewa \\ Yogyakarta 55281; e-mail: fikrihaekal1123@gmail.com; sofianmuhammad47@gmail.com; \\ windasabrina658@gmail.com \\ * Korespondensi: e-mail: fikrihaekal1123@gmail.com
}

\begin{abstract}
The spread of virus covid-19 nowadays has influenced the behavior of people around the world, with Indonesians are no exceptions. Shortly after President Joko Widodo announced 1 or 2 patient positive with covid-19, the public is seen doing panic buying in a number of modern retailers. In some cases like buying large amount of hand sanitizer until it became rare on the market. The effect of covid-19 also caused the government to established Large-Scale Social Restrictions (PSBB) policy in areas that going through high cases of covid-19 spreading with the aim of preventing chances of wider spread. However, whether the establishment of PSBB has an influence on consumptive behavior of people living in those areas?. To answer this problem, researchers conducted an experiment related to effectiveness of the establishment of PSBB policy to people in Banjarmasin. This city was chosen because it is one of the areas which the government adopted PSBB policy, making it easier for researchers to collecting necessary data in this study.
\end{abstract}

Keywords: covid-19, consumptive behavior, PSBB, Banjarmasin City

\begin{abstract}
Abstrak
Penyebaran virus covid-19 saat ini telah mempengaruhi perilaku masyarakat di dunia, tidak terkecuali masyarakat Indonesia. Tak lama setelah Presiden Joko Widodo mengumumkan 1 dan 2 pasien yang positif covid-19, masyarakat terlihat melakukan aksi panic buying di sejumlah ritel modern. Seperti dalam beberapa kasus ada yang membeli hand sanitizer dalam jumlah yang sangat banyak sehingga hand sanitizer menjadi sesuatu yang langka di pasaran. Pengaruh virus covid-19 ini juga menyebabkan pemerintah menetapkan Pembatasan Sosial Berskala Besar (PSBB) pada daerah-daerah yang mengalami kasus penyebaran covid-19 yang sedemikian rupa dengan tujuan mencegah kemungkinan penyebaran yang lebih luas. Namun, apakah penetapan PSBB tersebut memberikan pengaruh terhadap perilaku konsumtif masyarakat yang tinggal di daerah tersebut?. Untuk menjawab permasalahan ini, penulis melakukan penelitian eksperimen terkait efektivitas penetapan PSBB tersebut pada masyarakat kota Banjarmasin. Kota Banjarmasin dipilih karena merupakan salah satu daerah yang ditetapkannya PSBB oleh pemerintah. Sehingga memudahkan penulis dalam mengumpulkan data yang dibutuhkan dalam penelitian ini.
\end{abstract}

Kata kunci: covid-19, perilaku konsumtif, PSBB, kota Banjarmasin

\section{Pendahuluan}

Isu mengenai penyebaran covid-19 di Indonesia sudah terdengar sejak Februari 2020, kepastian masuknya virus corona ke dalam negeri baru dikonfirmasi pemerintah pada awal Maret 2020. Tak lama setelah Presiden Joko Widodo mengumumkan 1 dan 2 pasien yang 
positif covid-19, masyarakat terlihat melakukan aksi panic buying di sejumlah ritel modern. Hal ini membuktikan perilaku kepanikan masyarakat dalam menanggapi sebuah krisis patut diwaspadai (Bisnis.com, 2020).

Ditambah lagi dengan banyak penyebaran berita bohong atau hoax di media sosial yang hadir ditengah-tengah masa pandemi virus Corona atau covid-19 mendorong masyarakat yang berprilaku konsumtif (perilaku membelanjakan uang dalam jumlah besar). Menurut Kominfo tercatat 187 berita hoax di media sosial seperti FB, Twitter, dan Instagram selama masa pandemi virus Corona atau covid-19 ini muncul, sempat terjadi penurunan berita hoax namun kembali naik ketika ditemukan kasus pertama di Indonesia.Pendahuluan harus memberikan latar belakang yang jelas, pernyataan yang jelas dari masalah, literatur yang relevan pada subjek, pendekatan yang diusulkan atau solusi, dan nilai kebaruan dari penelitian yaitu inovasi.

Berita bohong atau hoax ini juga menambah kepanikan dimasyarakat, sehingga banyak dari masyarakat langsung mengambil keputusan untuk menimbun barang sebanyak-banyaknya karena khawatir mungkin saja akan terjadi lockdown sehingga dipastikan mereka tidak bisa lagi berbelanja bahan keperluan sehari-hari. Adapun barang-barang yang paling banyak di beli dan di cari adalah bahan dapur (gula, minyak, dan sabun dII), masker dan hand sanitizer.

Adanya upaya pemerintah dalam menerapkan sejumlah aturan bagi daerah yang mengajukan penetapan PSBB di daerahnya jika memenuhi kriteria yang ditetapkan. Pembatasan ini merupakan salah satu upaya untuk menekan penyebaran dan penularan virus corona Covid-19 di suatu daerah. Maka peneliti tertarik untuk menguji efektivitas dari penetapan PSBB tersebut sejauh mana efektivitasnya terhadap perilaku konsumtif masyarakat pada masa Covid-19 ini.

\section{Metode Penelitian}

Dalam penelitian ini, peneliti melakukan penelitian eksperimental. Menurut Gay dan Airisian dalam tulisan Fauziah "penelitian eksperimental adalah satu-satunya jenis penelitian yang dapat menguji hipotesis untuk membangun hubungan sebab dan akibat". Dan dalam hal ini peneliti ingin menguji hipotesis mengenai efektivitas dari penetapan PSBB yang dilakukan oleh pemerintah di masa covid-19 ini (Fauziah et al., 2020).

\section{a) Subjek Penelitian}

Subjek/ Partisipan penelitian ini berjumlah 10 orang. Partisipan adalah masyarakat yang tinggal di daerah yang ditetapkan PSBB oleh pemerintah baik yang sudah bekerja maupun tidak yang berumur 20 tahun keatas. Semua subjek yang peneliti ambil ini merupakan masyarakat kota Banjarmasin provinsi Kalimantan Selatan yang mampu mengoperasikan media sosial.

\section{b) Prosedur Pengambilan Sampel}

Peneliti menggunakan cluster random sampling dalam memilih sampel. Gay (2009: 129) mengatakan "cluster random sampling adalah proses pemilihan secara acak kelompok 
utuh, bukan individu dalam populasi yang ditentukan yang memiliki karakteristik yang sama". Pertimbangan lain dari penggunaan cluster random sampling adalah karena kepraktisan dan efisiensi waktu. Gay, Mills, dan Airasian (2011: 136) menjelaskan bahwa pengambilan sampel klaster melibatkan lebih sedikit waktu dan biaya dan umumnya lebih nyaman.

Dalam Penelitian ini, sampel diambil secara acak dari masyarakat yang tinggal di kota Banjarmasin. Skor di ambil dari seberapa banyak pengeluaran yang dilakukan oleh pastisipan sebelum dan sesudah ditetapkannya PSBB dalam membeli barang-barang yang bukan merupakan kebutuhan pokok.

Dalam penelitian ini penulis menggunakan teknik paired t-test (t sample berpasangan). Uji t sample berpasangan sering kali disebut sebagai paired-sampel t test. Uji t untuk data sampel berpasangan membandingkan rata-rata dua variabel untuk suatu grup sampel tunggal. Uji ini menghitung selisih antara nilai dua variabel untuk tiap kasus dan menguji apakah selisih rata-rata tersebut bernilai nol. Uji t berpasangan (paired t-test) umumnya menguji perbedaan antara dua pengamatan. Uji seperti ini dilakukan pada Subjek yang diuji untuk situasi sebelum dan sesudah proses, atau subjek yang berpasangan ataupun serupa (sejenis). Alasan dipilihnya jenis penelitian dan teknis analisis ini karena peneliti ingin mengetahui apakah ada perbedaan sebelum dan setelah dilakukan treatment pada masyarakat.

\section{c) Desain Penelitian}

Penelitian ini menggunakan penelitian asosiatif dengan pendekatan perilaku. Penelitian asosiatif adalah penelitian yang mencari hubungan hubungan antara dua variable atau lebih, dimana data yang digunakan melalui kuesioner yang dibagikan pada masyarakat sebelum dan sesudah mendapatkan pendekatan perilaku. Yang dimaksud pendekatan perilaku disini adalah berupa mengingatkan untuk tidak berperilaku konsumtif. Jadi partisipan akan diberikan pengingat (notification) serta instruksi setiap harinya melalui media sosial whatsapp untuk tidak berperilaku konsumtif selama pemberian perlakuan.

\section{d) Hipotesa Penelitian}

Hipotesis yang diajukan adalah:

H0: Penetapan PSBB tidak memberikan pengaruh terhadap perilaku konsumtif masyarakat pada masa covid-19.

Ha: Penetapan PSBB memberikan pengaruh dalam menurunkan perilaku konsumtif masyarakat pada masa covid-19.

Hipotesis dari kasus ini dapat ditulis menjadi: $\mathrm{Ho}: \mu 1=\mu 2$

$$
\mathrm{H} 1: \mu 1 \neq \mu 2
$$

\section{e) Uji T Berpasangan}

Uji-t berpasangan (paired t-test) adalah salah satu metode pengujian hipotesis dimana data yang digunakan tidak bebas (berpasangan). Ciri-ciri yang paling sering ditemui pada kasus yang berpasangan adalah satu individu (objek penelitian) mendapat 2 buah perlakuan yang berbeda. Walaupun menggunakan individu yang sama, peneliti tetap memperoleh 2 macam data sampel, yaitu data dari perlakuan pertama dan data dari perlakuan kedua. 


\section{f) Rumus Uji T Berpasangan}

Uji-t berpasangan (paired t-test) adalah salah satu metode pengujian hipotesis dimana data yang digunakan tidak bebas (berpasangan). Ciri-ciri yang paling sering ditemui pada kasus yang berpasangan adalah satu individu (objek penelitian) mendapat 2 buah perlakuan yang berbeda. Walaupun menggunakan individu yang sama, peneliti tetap memperoleh 2 macam data sampel, yaitu data dari perlakuan pertama dan data dari perlakuan kedua.

$$
\begin{array}{ll}
t=\frac{\bar{X}_{D}-\mu_{0}}{s_{D} / \sqrt{n}} . & \quad \bar{X}_{d}=\frac{\sum D}{n} \\
s_{d}=\sqrt{\frac{1}{n-1}\left\{\sum D^{2}-\frac{\left(\sum D\right)^{2}}{n}\right\}}
\end{array}
$$

Keterangan:

$\mathrm{D}=$ Selisih $\mathrm{x} 1$ dan $\mathrm{x} 2(\mathrm{x} 1-\mathrm{x} 2)$

$\mathrm{n}=$ Jumlah Sampel

$\mathrm{X}$ bar $=$ Rata-rata

$\mathrm{S} \mathrm{d}=$ Standar Deviasi dari $\mathrm{d}$.

g) Interpretasi

a) Untuk menginterpretasikan uji t-test terlebih dahulu harus ditentukan:

- Nilai signifikansi $\alpha$

- Df $($ degree of freedom $)=\mathrm{N}-\mathrm{k}$, khusus untuk paired sample t-test $\mathrm{df}=\mathrm{N}-1$

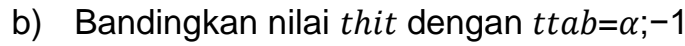

c) Apabila:

$t$ hit $>t$ tab $\rightarrow$ berbeda secara signifikan ( $\mathrm{H} 0$ ditolak dan Ha diterima).

$t$ hit $<t$ tab $\rightarrow$ tidak berbeda secara signifikan (H0 diterima dan Ha ditolak).

\section{Hasil dan Pembahasan}

Data perlakuan pertama dalam penelitian ini ditentukan melalui nilai hasil pretest dan data perlakuan kedua ditentukan melalui nilai hasil posttest. Data kedua perlakuan dapat dilihat pada tabel 1.

Tabel 1. Data nilai sebelum perlakuan (pretest) dan sesudah perlakuan (post test).

\begin{tabular}{|c|c|c|c|}
\hline & Responden & Data Sebelum (pretest) & $\begin{array}{c}\text { Data Sesudah } \\
\text { (posttest) }\end{array}$ \\
\hline 1. & Nur Fitriana & 500 & 100 \\
\hline 2. & Anggraini & 500 & 300 \\
\hline 3. & Mulya & 400 & 300 \\
\hline 4. & Rizky Amaliah & 450 & 100 \\
\hline 5. & Syabela Amalia & 600 & 1.200 \\
\hline 6. & Maulida & 300 & 500 \\
\hline 7. & Miftahul Jannah & 600 & 400 \\
\hline & Nur Puspita Sari & 300 & 100 \\
\hline
\end{tabular}




\begin{tabular}{clcc}
\hline Responden & Data Sebelum (pretest) & $\begin{array}{c}\text { Data Sesudah } \\
\text { (posttest) }\end{array}$ \\
\hline 9. & Lida & 600 & 600 \\
\hline 10. & Mardiana & 800 & 400 \\
\hline
\end{tabular}

Data pada tabel 1 dianalisis dengan uji-t menggunakan SPSS 16.0. Hasil analisis dapat dilihat pada tabel 2,3, dan 4 .

Tabel 2. Paired Samples Statistics

\begin{tabular}{llrrrr}
\hline & Mean & N & Std. Deviation & \multicolumn{2}{c}{ Std. Error Mean } \\
\hline Pair 1 & Sebelum & 505.00 & 10 & 153.569 & 48.563 \\
\cline { 2 - 6 } & Sesudah & 400.00 & 10 & 329.983 & 104.350 \\
\hline
\end{tabular}

Data pada tabel 2 menunjukan bahwa rata-rata pengeluaran sebelum dan sesudah penetapan pembatasan sosial bersekala besar (PSBB). Sebelum penetapan pembatasan sosial bersekala besar (PSBB) rata-rata pengeluaran dari 10 responden adalah 505.00, sementara setelah penetapan pembatasan sosial bersekala besar (PSBB) rata-rata pengeluaran adalah 400,00 rupiah.

Tabel 3. Paired Samples Correlations

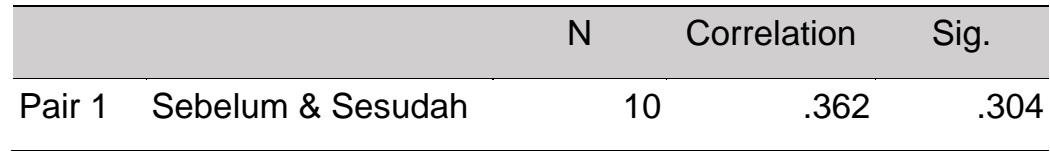

Data pada tabel 3 Hasil uji menunjukan bahwa korelasi antara dua variabel adalah sebesar 0,362 dengan signifikasi sebesaar 0,304. Hal ini menunjukan bahwa korelasi antara dua rata-rata pengeluaran sebelum dan sesudah penetapan PSBB adalah sigifikan.

Tabel 4. Paired Samples Test

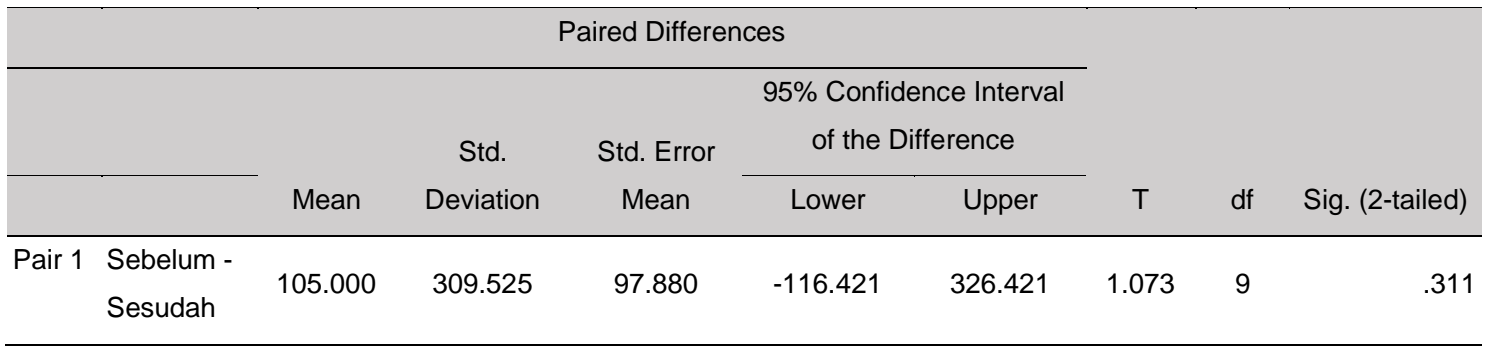

Tabel 4 menunjukkan hasil uji-t, t hitung sebesar $=1.073$ Dengan nilai signifikan a sebesar 0,05 , maka $t$ tabel $=2.262$. sehingga dapat kesimpulan bahwa $t$ hitung $<\mathrm{t}$ tabel, Ho diterima Ha ditolak. Artinya penetapan pembatasan sosial bersekala besar (PSBB) tidak memberikan pengaruh terhadap perilaku konsumtif masyarakat pada masa covid-19. Dengan kata lain, perlakuan yang dilakukan dalam penelitian tidak memberikan pengaruh sebelum dan sesudah diberikan pendekatan prilaku pengingat atau intruksi setiap harinya melalui media sosial whatsapp. 


\section{Kesimpulan}

Berdasarkan hasil analisis data, dengan demikian dapat disimpulkan bahwa penetapan pembatasan sosial bersekala besar (PSBB) yang dilakukan oleh pemerintah dan diberikannya perilaku pengingat untuk membatasi sifat konsumtif dalam penelitian ini tidak efektif untuk menurunkan prilaku konsumtif masyarakat pada masa covid-19.

\section{Daftar Pustaka}

Benarkah Konsumsi Masyarakat Berubah saat PSBB? | Ekonomi. (2020, April 13). Bisnis.Com. https://ekonomi.bisnis.com/read/20200413/9/1226462/benarkah-konsumsi-masyarakatberubah-saat-psbb

Fauziah, D., Mukhaiyar, \& Ratmanida. (2020). The Effectiveness of Roundtable Technique to Teach Writing Descriptive Text for Students with Low Self-Efficacy. 264-275. https://doi.org/10.2991/assehr.k.200306.044

Lina dan Rosyid, H.F. (1997). Perilaku Konsumtif Berdasarkan Locus of Control pada Remaja Putri. Jurnal Pemikiran dan Penelitian Psikologi. No. IV Tahun XI.

Mediatama, G. (2020, April 1). Bingung dengan pembatasan sosial skala besar? Ini bedanya dengan karantina wilayah - Page all. kontan.co.id. http://nasional.kontan.co.id/news/bingung-dengan-pembatasan-sosial-skala-besar-inibedanya-dengan-karantina-wilayah.

Naomi, Prima. dan Mayasari, lin. (2008). Faktor-Faktor Yang Mempengaruhi Siswa SMA Dalam Perilaku Pembelian Kompulsif: Perspektif Psikologi. Portal Jurnal UPI Tahun VII Ino. VIII oktober 2008

Nur Rohmi, A. (n.d.). Menkes Setujui PSBB DKI Jakarta: Berikut Pengertian, Syarat, dan Halhal yang Akan Dibatasi Halaman all. KOMPAS.com. Retrieved April 20, 2020, from https://www.kompas.com/tren/read/2020/04/07/080758265/menkes-setujui-psbb-dkijakarta-berikut-pengertian-syarat-dan-hal-hal-yang

Sumartono. (2002). Terperangkap dalam Iklan: Meneropong Imbas Pesan Iklan. Televisi. Bandung: Alfabeta.

Suyasa, P, Tommy Y.S \& Fransisca. (2005). Perbandingan Perilaku Konsumtif berdasarkan Metode Pembayaran.Jurnal 3Phorenesis.Vol.VII. No. II.

Tamtomo, A. B. (n.d.). INFOGRAFIK: Memahami Pembatasan Sosial Berskala Besar atau PSBB. Retrieved April 20, 2020, from https://www.kompas.com/tren/read/2020/04/07/122100065/infografik-memahamipembatasan-sosial-berskala-besar-atau-psbb 